\title{
Justice, Equality and Community: An Essay in Marxist Political Theory Vidhu Verma
}

Sage, New Delhi, Thousand Oaks, London, 2000, 220pp.

Hardback, ISBN: 0761993797.

The debate on justice in Marx's writings is as wide as it is contentious. Vidhu Verma's intricately argued book is a very worthwhile contribution to this debate. Verma identifies three approaches to justice within Marxist political theory: the Non-Juridical Approach (NJA), the Distributive Justice Approach (DJA), and the Beyond Justice Approach (BJA). It is the NJA that Verma seeks to defend against the other competing conceptions of justice.

To develop her NJA, Verma structures the book into five chapters. Chapter 1 offers a very helpful overview of the debate on justice in Marx's writings and Verma's concern here is to defend Marx against those who suggest that he does not have a theory of justice at all. Within this debate two interpretations of Marx's relation to justice are shown to dominate. One, the Justice thesis, rejects the idea that Marx condemns capitalism as immoral in terms of justice and instead argues that it is based on freedom; the other, the Injustice thesis, rejects the latter account and argues that Marx did condemn capitalism as unjust. As Verma notes, the ambiguities in Marx's writings certainly allow for both of these positions to be held; however, she exposes weaknesses in both of them. The Justice thesis, for example, by arguing that any norm of justice is tied to the prevailing society, must concomitantly argue that any notion of freedom must accord with the current mode of production. For Verma, the Justice thesis therefore offers an untenable notion of freedom that transcends current society: a possibility which they disallow for this notion of justice. In contrast, interpreting Marx only as a moral theorist and thereby ignoring his critical comments on morality and justice weakens the Injustice thesis. Verma therefore sees these two opposite readings of Marx as one-sided in their assertion that Marx provides a moral critique of capital or not. Instead, Verma seeks to overcome these oppositions by relating them to wider issues such as Marx's arguments over rights, equality, morality and exploitation. Verma therefore attempts to offer a more complete account of justice in Marx's writings through the NJA, which occupies the next three chapters of the book and the conclusion.

Verma argues that the NJA is non-juridical because it is an account of justice that is not prescriptive, in that it does not specify what institutions are to exist or what legal principles are to be followed in a new society. The NJA is also seen as being 'critical' because its concept of justice suggests the transcendence 
of existing social structures, and thus poses problems for liberal conceptions of justice, which accept the status quo. Verma is keen therefore to make the distinction between these two aspects of Marx's thought, because, as she realises, the ideal of building a new society raises more than a number of issues about its possibility. Indeed, it is on this aspect that Verma sees Marx making the assumption that once class-based differences are over there will be no conflicts in a post-capitalist society. Verma argues that this ignores the great differences that will persist between different groups around issues of sex, race or religion, for example, that would need to be dealt with. Even so, Verma still argues for the relevance of Marx's theory of justice, which, she argues, is still applicable to contemporary social problems.

Verma then contrasts the two inferior approaches to justice that have been gleaned from Marx's writings. The DJA, as its name suggests, focuses on Marx's distributive principles, which are the bases for his critique of capitalism. Justice is therefore only related to the distribution of wealth, income and material resources. The BJA sees justice merely as a formal and legal concept and suggests that the pursuit of justice is meaningless as communist society transcends justice. For Verma, both these approaches have weaknesses. The DJA is correct to emphasise justice in relation to distribution but it is wrong to stop at that point. Verma argues that her preferred NJA model links the issue of just distribution with freedom and equality in a non-juridical and nonexploitative society. As regards the BJA, Verma states that while this approach is invaluable in that it is attacking liberal conceptions of justice here and now, it fails to consider the distributive aspects of justice that Marx himself proposed. In contrast, Verma argues that the NJA approach enlarges Marx's notion of justice and links it to the definition of ends. It proffers a new society where goods are distributed on the basis of needs which themselves are entwined with the self-realisation of the members of this new community.

The emphasis on community is also important in Verma's critique of the juridical model, which has an individualist conception of rights. Using Marx's critique of liberal conceptions of rights, she argues that rights can only be exercised in community with others and not prior to the formation of a political community. She then goes on to examine Marx's theory of exploitation, which she defines in the classical Marxist sense as the appropriation of surplus value in the labour process. She argues, however, that a wider theory of justice is needed to grasp the existence of exploitation in other spheres of life than simply the workplace. Injustices outside, she maintains, are not necessarily related to the buying and selling of commodities, but to gender or race inequalities, or the despoliation of the planet. Verma notes the difficulties in being prescriptive about overcoming these conflicts and creating a new society as we saw above, but despite this she does think that this is ultimately, not only possible, but desirable. Hence, Verma has clearly set out 
the theoretical groundwork for searching for this new and better society but, as she says herself, the 'NJA must be transcended by a theory of justice that explores the institutional domain in which' the 'various demands for justice can be fulfilled' (p. 196).

Ian Fraser

Department of Economics \& Politics, Nottingham Trent University. 